\title{
Erratum: Modeling the course of amyotrophic lateral sclerosis
}

Christina Fournier \& Jonathan D Glass

Nat. Biotechnol. 33, 45-47 (2015); published online 9 January 2015; corrected after print 30 April 2015

In the version of this article initially published, the number of patients said to be included in the PRO-ACT database was given as 1,822 . There are 8,635 patients in the database to date, of which 1,822 were included in the crowdsourcing challenge. The error has been corrected in the HTML and PDF versions of the article.

\section{Erratum: Selling long life}

\section{Christopher Thomas Scott \& Laura DeFrancesco}

Nat. Biotechnol. 33, 31-40 (2015); published online 9 January 2015; corrected after print 30 April 2015

In the version of this article initially published, Retrotope Inc. was included in Table 1 in the "Walking dead" category. Nature Biotechnology has since been informed by Retrotope management that the company raised \$10 million in seed funding in 2014. Retrotope has been removed from Table 1. The error has been corrected in the HTML and PDF versions of the article.

\section{Corrigendum: Taking charge of siRNA delivery}

\section{Anastasia Khvorova, Maire F Osborn \& Matthew R Hassler}

Nat. Biotechnol. 32, 1197-1198 (2014); published online 9 December 2014; corrected after print 29 April 2015

In the version of this article initially published, in two instances molecules were misidentified in the text. The last sentence in the legend of Figure 1 should have read, "a charged phosphodiester," rather than "a phosphatediester." On p.1197, third column, first paragraph, "intracellular phosphodiesterases..." should have read, "intracellular thioesterases..." The errors have been corrected in the HTML and PDF versions of the article. 